\title{
Combining hard-part and DNA analyses of scats with biologging and stable isotopes can reveal different diet compositions and feeding strategies within a fur seal population
}

\author{
T. Jeanniard-du-Dot ${ }^{1,2}$, A. C. Thomas ${ }^{2}$, Y. Cherel $^{1}$, A. W. Trites ${ }^{2}$, C. Guinet ${ }^{1}$ \\ ${ }^{1}$ Centre d'Etudes Biologiques de Chizé, UMR 7372 du CNRS-Université de La Rochelle, 79360 Villiers en Bois, France \\ ${ }^{2}$ Marine Mammal Research Unit, 2202 Main Mall, Aquatic Ecosystems Research Laboratory (AERL) Building, \\ University of British Columbia, Vancouver, BC V6T1Z4, Canada
}

\begin{abstract}
Accurately estimating predators' diets at relevant spatial and temporal scales is key to understanding animals' energetics and fitness, particularly in populations whose decline might be related to their diet such as northern fur seals Callorhinus ursinus. Our goals were to improve the accuracy of diet estimates and extend understanding of feeding ecology by combining 2 scat-based methods of diet determination (hard-part identification and DNA-metabarcoding) with stable isotope measurements and individual behavioural data. We collected 98 scats on a northern fur seal breeding colony. We also tracked 20 females with biologgers, and took blood samples to determine $\delta^{13} \mathrm{C}$ and $\delta^{15} \mathrm{~N}$ values as proxies for seal foraging habitat and diet. Results show that diet composition from hard-parts analysis corresponded well with DNA results, with DNA yielding a greater diversity of prey species at a finer taxonomic level. Overall, scat-based methods showed that seals mostly fed on neritic shelf-associated prey. Cluster analyses of combined hard-parts and DNA results however identified 2 diet groups, one mostly neritic and the other mostly pelagic. Stable isotopes and behavioural data revealed that $40 \%$ of seals fed in oceanic waters on pelagic prey. This is more than indicated by scat-based analyses, which are likely biased towards animals foraging closest to the colony and underestimate some dietary specializations within the population. Consequently, the combination of multiple methods for diet identification with at-sea tracking of individuals can help identify and quantify specialist groups within a population and provide a wider spatial and temporal ecological context for dietary analysis.
\end{abstract}

${ }^{*}$ Corresponding author: tiphainejdd@gmail.com

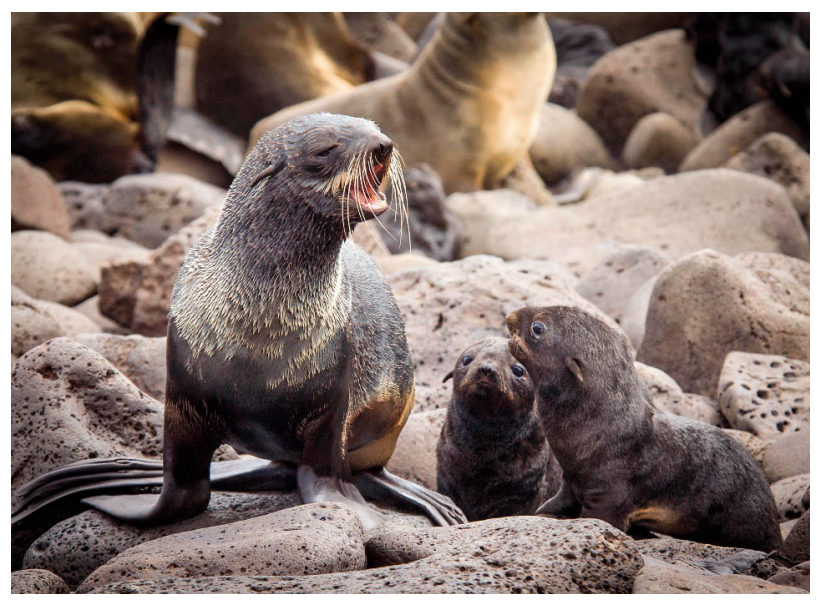

Northern fur seal female with pup on breeding colony on St. Paul Island, AK, USA in the Bering Sea.

Photo: Andrew Trites

KEY WORDS: Diet . DNA-metabarcoding $\cdot$ Hardparts identification . Stable isotopes · Telemetry . Biologging $\cdot$ Foraging ecology $\cdot$ Northern fur seals

\section{INTRODUCTION}

Accurate estimates of predators' diets are central to our understanding of the functioning and structure of ecosystems (prey-predator interactions, food web structures, etc.; Paine 1980, Stephens \& Krebs 1986) as well as the biology and energetics of animals in their habitat, their fitness, and population dynamics

(C) The authors 2017. Open Access under Creative Commons by Attribution Licence. Use, distribution and reproduction are unrestricted. Authors and original publication must be credited. 
(Rosen \& Trites 2000, Romano et al. 2006). As ecosystems and trophic webs are highly dynamic, the coupling of traditional diet information with foraging location data can add a spatial and temporal dimension to dietary estimates (Tremblay \& Cherel 2003, Cherel et al. 2007). Numerous studies have focused on developing accurate methods for qualitative estimate of diet of free-ranging animals (Pierce \& Boyle 1991, Tollit et al. 2010). In terrestrial predators, direct observations of feeding can provide useful qualitative and quantitative information on these diets (Raboy \& Dietz 2004). However, direct observation of diet or feeding is difficult to reliably obtain in most free-ranging animals, including aquatic predators, leading to development of indirect methods to reconstruct diets (Pierce \& Boyle 1991, Kelly 2000).

In marine mammals, non-invasive diet studies have traditionally been done by identifying the undigested hard-parts remains of prey found in feces (scats) or to a lesser extent in spews (Perez \& Bigg 1986, Gudmundson et al. 2003). These identification methods can provide both qualitative and quantitative information on diets, such as taxon, size and relative number of prey ingested (Tollit et al. 2003). However, passage of hard-parts is biased by differential digestion or retention rates of prey parts, depending on species and sizes of prey consumed, and on species, sex, activity level, gastrointestinal tract morphology and meal size of predators. These biases can lead to under- or over-estimation of prey occurrence (or size of prey consumed) in the diets (Harvey \& Antonelis 1994, Tollit et al. 1997, Arim \& Naya 2003), although correction factors can be applied to account for some of them (Antonelis et al. 1997, Tollit et al. 1997). In addition, assumptions underlying how methods based on presence-absence data determine the relative proportion of each species consumed are often not met (Olesiuk et al. 1990).

More recently, methodological advancements have increased interest in molecular-based tools that overcome some of the limitations of hard-parts analyses (Casper et al. 2007a, Deagle et al. 2009, Cristescu 2014). Among them, the DNA metabarcoding method allows species or groups of organisms to be identified within a sample by employing universal or semi-universal PCR primer sets. This molecular method generally relies on high-throughput DNA sequencing to identify species of prey consumed, the DNA of which is amplified from the soft organic matter of the feces. It is non-invasive, has the advantages of being quick and relatively inexpensive, and is more sensitive than hard-part remains methods (Deagle et al. 2009). For example, DNA analyses detected prey to a finer taxonomic level than hard-parts analyses in Steller sea lions Eumetopia jubatus and harbour seals Phoca vitulina (Tollit et al. 2009, Thomas et al. 2017). The quantitative capabilities of DNA metabarcoding (i.e. the relationship between DNA sequence proportions from scats and prey biomass) are still being evaluated; however, metabarcoding can also be used to produce information on occurrence of prey species which can be directly compared to the results of hard-parts analysis (Casper et al. 2007a, Deagle et al. 2010, Thomas et al. 2014).

In any case, analyses of scat samples have proven to be a useful way to estimate diet composition of pinnipeds. However, scats only represent what animals recently consumed (during the previous $\sim 48 \mathrm{~h}$; Orr \& Harvey 2001, Casper et al. 2007a). They provide a short temporal window into the dietary habits of animals that might not be representative of longerterm feeding behaviours and preferences of individuals, particularly in a potentially variable environment. Stable isotope concentrations in blood, hair and bone synthesize dietary information over longer timescales, from weeks to years depending on substrate turnover rate. $\delta^{15} \mathrm{~N}$ provides insights into the trophic level at which the consumer has fed (Wada et al. 1991, Hobson \& Welch 1992), while $\delta^{13} \mathrm{C}$ indicates the foraging location based on the isotopic composition of primary producers at the base of the food chain (France 1995, Burton \& Koch 1999). Numerous studies have used these stable isotopes to determine feeding ecology of predators, food web structures and dynamics, habitat partitioning, foraging specialization, life history events, etc. (Carreon-Martinez \& Heath 2010, Newsome et al. 2010, Kernaléguen et al. 2015). Stable isotopes complement the qualitative and/or quantitative shorter-term information provided by scat-based methods.

Most of the world population of northern fur seals Callorhinus ursinus once bred on the Pribilof Islands in the Bering Sea. However, this population has declined by $\sim 6 \% \mathrm{yr}^{-1}$ for the last $30 \mathrm{yr}$, to about $45 \%$ of the world population, with no sign that the decline is slowing down (Towell et al. 2006, Ward 2016), and is listed as 'Depleted' under the Marine Mammal Protection Act. The decline has coincided with a major environmental change that has altered the distribution and relative abundances of different species of fish in the Bering Sea (Anderson et al. 1997, Anderson \& Piatt 1999). The decline also corresponds with a decrease in squid in the fur seal diet in the Bering Sea, and an increase in the dominance of walleye pollock from $\sim 35 \%$ in the $196 \mathrm{~s}-1970$ s to $\sim 70 \%$ in the 1990s (Perez \& Bigg 1986, Gudmundson et al. 2006, 
Sinclair et al. 2008). As the energy content of walleye pollock is generally lower than that of fish species previously dominant in the diet of northern fur seals, such as herring and capelin (Vollenweider et al. 2011), this change in diet probably affects the foraging efficiency of lactating females and their capacity to successfully reproduce. Interestingly, a small breeding colony recently established on Bogoslof Island within the deep basin of the Bering Sea has been steadily increasing. The diet of these 'Bogoslof' seals seems to differ from the 'Pribilof' ones and contains more mid-water mesopelagic fish and gonatid squid and fewer walleye pollock (Zeppelin \& Orr 2010). Assessing foraging strategies and diets is thus important for understanding the balance between energy input from food, and the energy spent foraging.

The Bering Sea, where northern fur seals forage during the breeding season, is composed of a shallow continental shelf and a deep oceanic basin, separated by a shelf break. The different bathymetric and hydrographic structures are associated with different fish assemblages. Northern fur seals feed widely in the Bering Sea, but appear to have foraging areas that depend upon the location of the breeding beaches (Robson et al. 2004, Kuhn et al. 2014). These foraging areas determine northern fur seals' foraging behaviours, dive patterns and ultimately their diets (Sinclair et al. 1994, Antonelis et al. 1997) within yearly environmental conditions (Gentry \& Kooyman 1986). It is thus important to assess diet composition and foraging behaviours of individual female fur seals to better understand foraging efficiency and reproduction success within specific environmental conditions. Combining telemetric and isotopic data of individuals with the hard-parts and DNA-based methods for population diet estimates can provide a better understanding of foraging strategies and diets of individuals and help disentangle spatial, trophic and physiological differences within a given population (Newsome et al. 2010, Thiebot et al. 2015, Cherel et al. 2016).

Consequently, within the context of the northern fur seal population decline in the Bering Sea, our first goal was to provide accurate diet estimates for northern fur seals on the Pribilof Islands by comparing and pairing DNA and hard-parts analyses of scat samples, thereby creating enhanced fur seal diet data. We also aimed to provide a spatial and temporal context for the dietary analysis using isotopic values of blood samples and data on foraging locations for 20 lactating females that pupped on the same rookery where the scats were collected. We thus sought to assess the reliability of current descriptions of fur seal diets, and ways in which the diet estimates might be corrected to better reflect the diet and feeding behaviours and ecology of northern fur seals breeding on the Pribilof Islands at relevant spatial and temporal scales.

\section{MATERIALS AND METHODS}

\section{Data collection}

All samples were obtained from Reef Rookery on St. Paul Island (Bering Sea, Alaska, 57 $11^{\prime} \mathrm{N}$, $170^{\circ} 28^{\prime} \mathrm{W}$ ) during August-September 2011 under US National Marine Fisheries Service (NMFS) permit \#14329-01 and University of British Columbia (UBC) animal care permit \#A10-0364. We collected 98 scats in August-September 2011, more than the number required to reach the maximum prey diversity (Zeppelin \& Orr 2010). Fur seal colonies are made of harems with multiple females within males' territories. The female/male ratio is high on the colony, so the probability of collecting scats from females is higher than for males. In addition, males fast on land while guarding their territory and as such are unlikely to defecate much during their extended stay on the colony. Finally, we tried to select scats of a specific size to avoid male scats, which are larger than those of females, given the sexual dimorphism. Despite these efforts, we may have collected scats other than from female fur seals, even though we estimate the likelihood as quite low. Each scat was frozen at $-20^{\circ} \mathrm{C}$ until processing at the UBC Marine Mammal Research Unit laboratory in Vancouver, Canada. Scat samples came from unknown individuals. Biologging data and blood samples for isotopic measurements were collected from 20 mature, lactating northern fur seals with a confirmed suckling pup. Randomly selected seals were restrained and anesthetised using isoflurane gas anesthesia under veterinarian supervision. Standard morphometric measurements were made to the nearest $0.5 \mathrm{~cm}$, and mass was recorded to $\pm 0.2 \mathrm{~kg}$.

\section{Morphological identification from hard-parts in scats and prey size}

Scats were thawed and transferred into a nylon mesh paint-strainer lining a $500 \mathrm{ml}$ disposable container. A $95 \%$ ethanol solution was added to the samples, and the scat matrix was separated from the hard 
prey remains by manual homogenization. The hardparts contained in the mesh bag were removed for cleaning procedures and analysis following a standard protocol (Trites \& Calkins 2008). Cleaned and dried hard-parts were sorted out and identified to lowest possible taxon by Pacific IDentifications (Victoria, BC) using a reference collection of prey species skeletons. Types of hard-part present, the species from which they came, the estimated size of the prey by species, and the minimum number of individuals present were recorded. Unknown prey items were categorized as 'unidentified' and excluded from analysis. The relative diet composition of fur seals was determined by first calculating the frequency of occurrence (FO) of a specific prey item as the percentage of scats collected that contained it. Second, the proportion of a specific prey in the overall diet (adding up to $100 \%$ ) was estimated using the splitsample frequency of occurrence (SSFO) (Olesiuk et al. 1990).

\section{Prey species identification from DNA sequences analyses}

Ethanol-preserved scat organic matter (matrix) was subsampled from thawed scats and used for genetic analyses. DNA extraction was performed following the protocol from Thomas et al. (2014) on approximately $20 \mathrm{mg}$ of scat sediment material from the same scats analysed for hard-part remains. Extraction was done using QIAamp DNA Stool Mini kit (Qiagen) and eluted in $100 \mu$ l elution buffer $(10 \mathrm{mM}$ Tris-Cl, 0.5 mM EDTA; pH 9.0).

The scat DNA metabarcoding protocol used for this study followed the procedures outlined in Thomas et al. (2016). In brief, a 260 bp fragment of the $16 \mathrm{~S}$ mitochondrial ribosomal gene was amplified by PCR from each scat sample using the Qiagen Multiplex PCR kit. This reaction contained 2 different primer sets, which were developed to amplify a species-diagnostic region of $16 \mathrm{~S}$ for both chordates and cephalopods (Deagle et al. 2009). Sample identification was done using a 2-tiered labelling approach, employing 96 uniquely labelled forward/ reverse $(F / R)$ primer sets and the ligation of barcoded sequencing adapters to sample amplicon pools. Sequencing was done on an Illumina MiSeq using the MiSeq Reagent Kit v2 (300 cycles) for SE $300 \mathrm{bp}$ reads encompassing both primers and primer tags.

Demultiplexing of DNA sequences was done with the MiSeq platform itself (separating pools of
96 samples by adapter sequence) and in the software package QIIME (further separating samples by F/R primer tags) (Caporaso et al. 2010). For a sequence to be assigned to a sample, a perfect sequence match was required for the F/R priming regions and both primer tags. This double indexing approach mitigates potential issues with tag jumping during sequencing library prep (Schnell et al. 2015). Taxonomic identification of prey species DNA was performed with a nucleotide BLAST search for each sequence against a reference database of potential prey, using a minimum similarity threshold (Thomas et al. 2016). To ensure that no major prey group was missing from the existing database, we also applied a clustering approach with scat sequences, picking a representative of each cluster and applying a GenBank query to add any new prey species to our database that were not there initially (Altschul et al. 1990, Edgar 2010). More details on the procedure can be found in Thomas et al. (2016). DNA detections of prey species in samples were treated as occurrences (presence/absence), similar to the treatment of prey hard-part information.

\section{Combined scat-based prey associations}

We combined the results from the hard-part and the DNA analyses by merging occurrence of unique prey species detected by either technique per individual scat. For example, when a species of salmon was detected with DNA analysis and presence of unidentified salmon was detected from hard-parts within the same scat, we considered hard-part remains were coming from the specific species identified by DNA sequencing and did not duplicate occurrence of salmon. We did the same for cephalopod species, and obtained a combined presenceabsence matrix of individual prey species per scat. FO and SSFO in the diet from DNA analyses of DNA and hard-parts combined were calculated as above.

Association between prey groups within individual scats were identified and illustrated using a cluster analyses (hclust in the stats package in $\mathrm{R}$ 3.1.3). We first calculated the gamma coefficient (Goodman \& Kruskal 1954) for each pair of prey groups from a presence-absence matrix of prey within the different scats. The distances between prey groups were estimated as 1 - gamma and were used as the dissimilarity matrix for the cluster analysis (with the 'complete' method). 


\section{Foraging locations and behaviours from biologging data}

Each captured female fur seal was equipped with a Fastloc GPS data logger (MK10, Wildlife Computers) glued to their fur roughly $8 \mathrm{~cm}$ below their shoulder blades. The data loggers also recorded depth at $1 \mathrm{~Hz}$, and were used to identify foraging locations and provide diving data to determine whether dives were benthic or pelagic (Tremblay \& Cherel 2000). Upon recovery from anesthesia, animals were allowed to return to the colony and to go on a single foraging trip before recapture upon their return on land. The GPS logger was then retrieved by cutting the hair.

We used depth data recorded by the biologgers to determine diving behaviours using a custom-made $\mathrm{R}$ program previously developed for Antarctic fur seals. Dives were defined as periods of time that animals spent under water below a minimum depth of $3 \mathrm{~m}$ and for a minimum of $4 \mathrm{~s}$ until they went back to the surface. Any drift in the pressure sensors or error spikes were corrected prior to analysis. Distances traveled at the surface of the ocean (horizontal distances) were calculated by measuring the linear distance between 2 successive GPS locations taking into account the curvature of the Earth using the Haversine formula (Sinnott 1984). GPS locations have a high spatial and temporal resolution (they were set to record a location every $5 \mathrm{~min}$ ), so GPS tracks did not require interpolation or filtering (Tremblay et al. 2006). Trip durations were estimated from the biologgers that recorded time in the water versus time on land with a wet/dry sensor.

\section{Stable isotopes}

Blood samples were collected from the back flipper while the animals were anesthetized before the foraging trip as well as upon recapture. They were drawn using Monovette syringes (Sarstedt) coated with Li-Heparin. Plasma was isolated from red blood cells (RBC) by centrifugation at $1000 \times g$ for $10 \mathrm{~min}$. Samples were frozen at $-20^{\circ} \mathrm{C}$ before analyses in the laboratory.

Stable isotope analyses were performed at the LIENSs laboratory (La Rochelle University). Red blood cells (collected before the seal's foraging trip) and plasma samples (collected before and after the seal's foraging trip) were freeze-dried and powdered. Blood plasma can contain high and/or variable lipid content in animals (Cherel et al. 2005), so we performed a lipid extraction using cyclohexane follow- ing the method used for elephant seals Mirounga leonina (Authier et al. 2012). Blood subsamples were weighed $(\sim 0.4 \mathrm{mg})$ with a microbalance, packed in tin containers, and nitrogen and carbon isotope ratios were determined by a continuous flow mass spectrometer (Micromass Isoprime) coupled with an elemental analyser (Euro Vector EA 3024). Stable isotope concentrations were expressed in conventional notation $\left(\delta \mathrm{X}=\left[\mathrm{R}_{\text {sample }} / \mathrm{R}_{\text {standard }}-1\right] \times 1000\right)$, where $\mathrm{X}$ is ${ }^{13} \mathrm{C}$ or ${ }^{15} \mathrm{~N}$ and $\mathrm{R}$ is the corresponding ratio, i.e. ${ }^{13} \mathrm{C}:{ }^{12} \mathrm{C}$ or ${ }^{15} \mathrm{~N}:{ }^{14} \mathrm{~N}$. $\mathrm{R}_{\text {standard }}$ is Vienna PeeDee Belemnite and atmospheric $\mathrm{N}_{2}$ for $\delta^{13} \mathrm{C}$ and $\delta^{15} \mathrm{~N}$, respectively. The units are expressed in parts per mil (\%). Replicate measurements of internal laboratory standards (acetanilide) indicate measurement errors $<0.10 \%$ for both $\delta^{13} \mathrm{C}$ and $\delta^{15} \mathrm{~N}$.

RBC and plasma have different turnover rates. Plasma isotopic turnover is considered to be 10 to $15 \mathrm{~d}$, i.e. plasma $\delta^{13} \mathrm{C}$ and $\delta^{15} \mathrm{~N}$ values reflect the foraging strategy during the trip at sea we monitored. $\mathrm{RBC}$ isotopic turnover is longer at $\sim 2$ mo or longer, i.e. the change in RBC isotopic values reflects the foraging habitat and diet over a greater temporal scale than a single foraging trip (Kurle 2002). Consequently, overlaps in temporal windows between isotopes in RBC before the foraging trip and plasma after the foraging trip, and between isotopes in plasma before and after the foraging trip, were estimated at $15 \%$ or less on average. Foraging strategies (foraging habitat and diet/trophic position) were estimated during the recorded foraging trip at sea by looking at the relationship between $\delta^{13} \mathrm{C}$ and $\delta^{15} \mathrm{~N}$ values collected after the foraging trip (and thus representative of strategies during the 1 to $2 \mathrm{wk}$ prior to blood collection). Temporal consistency in isotopic values, and thus specialization in foraging habitat and diet/trophic level, was assessed using linear regressions (' $\mathrm{lm}$ ' in the stats package in $\mathrm{R}$ 3.3.0) between plasma $\delta^{13} \mathrm{C}$ or $\delta^{15} \mathrm{~N}$ values before and after foraging trip (shortterm), and between $\delta^{13} \mathrm{C}$ and $\delta^{15} \mathrm{~N}$ RBC values collected before the foraging trip and plasma isotopic levels collected after the foraging trip (mid-term).

\section{RESULTS}

\section{Scats hard-part remains analyses}

At least 14 prey species from 11 taxonomic families were found in the scats collected on Reef Rookery (including fish, cephalopods and discarded parasitic worms). There were no identifiable hard-parts in 38 of the 98 scats collected, so the hard-part analyses 


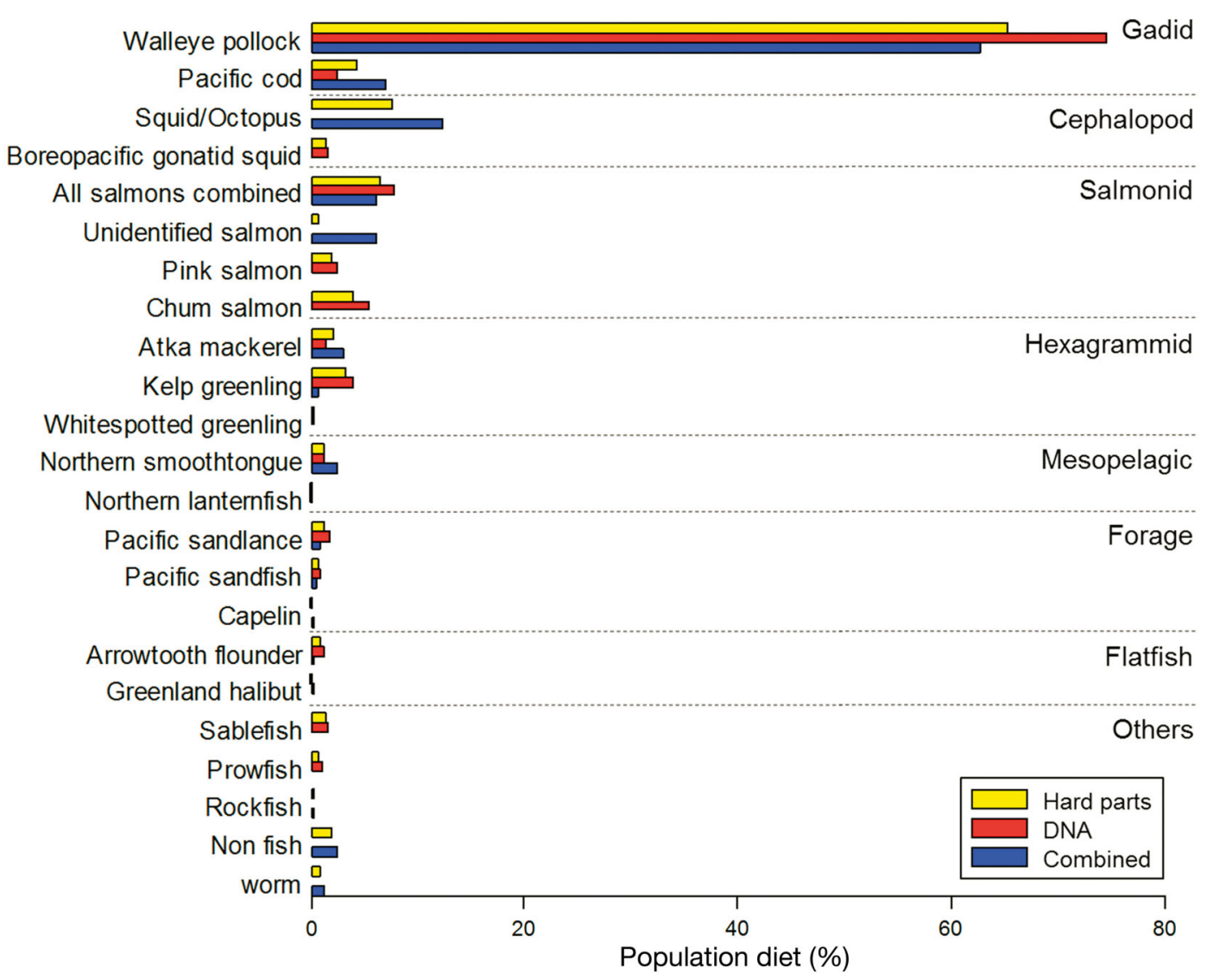

Fig. 1. Proportion of prey species in the diet (split sample frequency of occurrence, SSFO) of northern fur seals in scats collected from the breeding colony on Reef Rookery, St. Paul Island, Bering Sea, Alaska during August-September 2011. SSFO results are shown for hard-part remains analysis (yellow, $\mathrm{n}=60$ ), DNA analysis (red, $\mathrm{n}=98$ ) and for both techniques combined (blue, $\mathrm{n}=98$ ). Frequency of occurrence $(F O)$ and SSFO values are shown in Table S1 in the Supplement

were performed on only 60 scats. On average $( \pm \mathrm{SD})$ $1.5 \pm 0.1$ species were detected per scat with the hard-part technique. Only 1 species was detected per scat in more than $70 \%$ of scats, with a maximum of 6 species detected in 1 scat (Fig. S1 in the Supplement at www.intres.com/articles/suppl/m584p001 _supp.pdf). Based on the FO of different prey species (Fig. 1), the most ubiquitous prey was walleye pollock Theragra chalcogramma (present in $\sim 75 \%$ of scats), followed by salmon (in $\sim 30 \%$ of scats), cephalopods (squids and octopuses, in $\sim 18 \%$ of scats) and Atka mackerel Pleurogrammus monopterygius (in $\sim 10 \%$ of scats). The prey species were categorized in different taxonomic or ecological groups, according to their importance in the diet (Fig. 1,
Table 1). FO of each of these groups were then converted into relative proportion of prey in the diet using the SSFO method (Olesiuk 1993). The main prey category in the diet of Reef Rookery fur seals

Table 1. Frequency of occurrence (FO) and split-sampling frequency of occurrence (SSFO) of prey groups in scats of northern fur seals collected on Reef Rookery, St. Paul Island, Bering Sea, Alaska during the breeding season 2011, showing values obtained from identification of hard-part remains, DNA analysis and for both methods combined

\begin{tabular}{|c|c|c|c|c|c|c|c|c|c|}
\hline \multirow{2}{*}{ Prey group } & \multicolumn{3}{|c|}{ Hard-part remains } & \multicolumn{3}{|c|}{ DNA analysis } & \multicolumn{3}{|c|}{ Combined } \\
\hline & $\begin{array}{l}\mathrm{FO} \\
(\%)\end{array}$ & $\begin{array}{c}\text { SSFO } \\
(\%)\end{array}$ & Rank & $\begin{array}{l}\mathrm{FO} \\
(\%)\end{array}$ & $\begin{array}{c}\text { SSFO } \\
(\%)\end{array}$ & Rank & $\begin{array}{l}\mathrm{FO} \\
(\%)\end{array}$ & $\begin{array}{c}\text { SSFO } \\
(\%)\end{array}$ & Rank \\
\hline Gadids & 83.3 & 68.9 & 1 & 91.4 & 77.1 & 1 & 87.7 & 69.6 & 1 \\
\hline Cephalopods & 20.0 & 12.6 & 2 & 2.9 & 1.6 & 8 & 14.8 & 8.9 & 2 \\
\hline Salmonids & 15.0 & 6.4 & 3 & 15.7 & 7.8 & 2 & 17.3 & 6.5 & 3 \\
\hline Hexagrammids & 13.3 & 3.6 & 5 & 12.9 & 5.6 & 3 & 14.8 & 5.4 & 4 \\
\hline Forage fish & 5.0 & 1.5 & 7 & 7.1 & 2.5 & 4 & 7.4 & 2.1 & 6 \\
\hline Mesopelagic fish & 5.0 & 2.6 & 6 & 4.3 & 1.3 & 7 & 4.9 & 1.4 & 7 \\
\hline Flatfish & 1.7 & 0.3 & 8 & 4.3 & 1.5 & 6 & 3.7 & 1.1 & 8 \\
\hline Others & 7.7 & 4.2 & 4 & 7.1 & 2.6 & 5 & 12.3 & 5.1 & 5 \\
\hline
\end{tabular}


was gadids ( $69 \%)$, mostly composed of walleye pollock, followed by cephalopods (squids and octopuses of unknown species, $12.6 \%)$, salmonids $(6.4 \%)$ and hexagrammids $(3.6 \%$, mostly atka mackerel). Flatfish, forage fish, mesopelagic fish, rockfish and others made up the remaining $8.5 \%$ in the diet.

\section{Scat DNA analyses}

The organic matter in the collected scats was too dry or degraded to reliably detect prey species in 27 of the 98 scats collected. In the remaining 71 scats, the average number of prey sequences per sample was 3882, after performing all filtering steps and removing predator DNA sequences. Sixteen species of prey were detected in total with the DNAmetabarcoding method. On average, $1.6 \pm 0.2$ species were detected per scat (with a maximum of 8 species in a single scat), which is not significantly greater than the $1.5 \pm 0.1$ species determined from the hard-parts technique ( $p<0.05$; Fig. S1). Gadids (particularly walleye pollock) were the most ubiquitous prey found with this technique (in $>90 \%$ of scats; Fig. 1, Table 1). Overall, DNA analyses detected fewer cephalopods (1.6\%) than hard-parts analyses but results from the 2 methods were quite consistent for other species. The DNA method was however able to detect prey at the species level better than the hard-parts method (such as for salmon or cephalopod species; see Fig. 1). There were 21 scats in which no hard-parts were recovered but DNA analyses detected prey and 4 scats where hard-parts were recovered but no species detected from DNA. Species detected by DNA in these 21 scats were mostly walleye pollock $(\mathrm{n}=16)$; less frequent prey species included Pacific cod Gadus microcephalus, kelp greenling Hexagrammos decagrammus and sablefish Anoplopoma fimbria ( $\mathrm{n}=2 \mathrm{each}$ ).

\section{Combined hard-parts and DNA analyses}

There were 146 occurrences of prey in 81 scats with combined results from both methods (i.e. $1.8 \pm$ 0.1 prey items per scat), of which 56 were detected only with DNA analyses, 27 only with the hard-parts method, and 63 with both techniques. Both the FO of prey and their relative importance in the diet (SSFO) were quite consistent between methods for all prey types except cephalopods, and results from the combined method were intermediary to those obtained using each method alone (Fig. 1, Table 1). The major difference between results obtained using the 2 methods was for cephalopods $(\sim 12.6 \%$ SSFO in hardparts analysis compared to $\sim 1.6 \%$ using the DNA method, and $8.9 \%$ in the combined analysis). The numbers of scats containing multiple prey items increased from $\sim 25 \%$ using hard-parts analysis and $\sim 30 \%$ using the DNA method, to $\sim 40 \%$ using the combined method.

\section{Prey association}

Hierarchical cluster analyses from the combined DNA and hard-parts results showed that gadids and cephalopods were ubiquitous but, based on other prey, there were 2 main clusters that were not randomly distributed in the fur seal diet (Fig. 2). The first cluster was made up of forage fish, including hexagrammids, and flatfish, while the second cluster comprised mesopelagic fish, salmons and other types of prey. The association of pollock and cephalopods with the second cluster was not as strong as with the first one. The numbers of prey found in each scat were not high enough to yield accurate cluster analyses from the non-combined results.

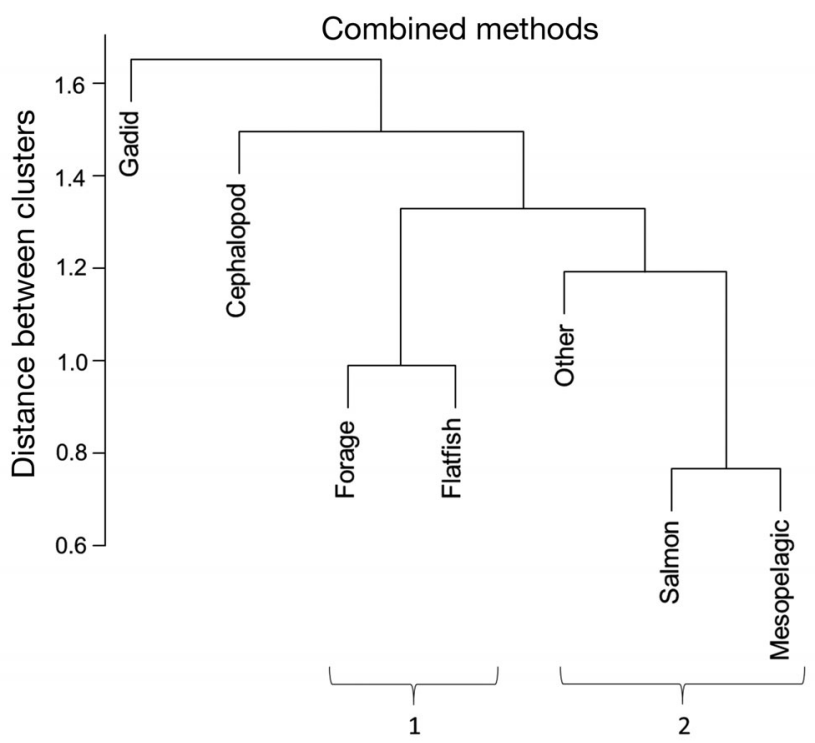

Fig. 2. Hierarchical cluster dendrogram of prey groups found in 81 northern fur seals scats from Reef Rookery on St. Paul Island, Bering Sea, Alaska, in August-September 2011, based on combined results of DNA analyses of organic remains and morphological identification of hard-parts. Gadids were found in $99 \%$ of the collected scats, and cephalopods in $25 \%$. They were associated to 2 clusters identified from less frequently occurring prey groups: (1) flatfish and forage fish (including hexagrammids) and (2) salmons, mesopelagic fish and others 


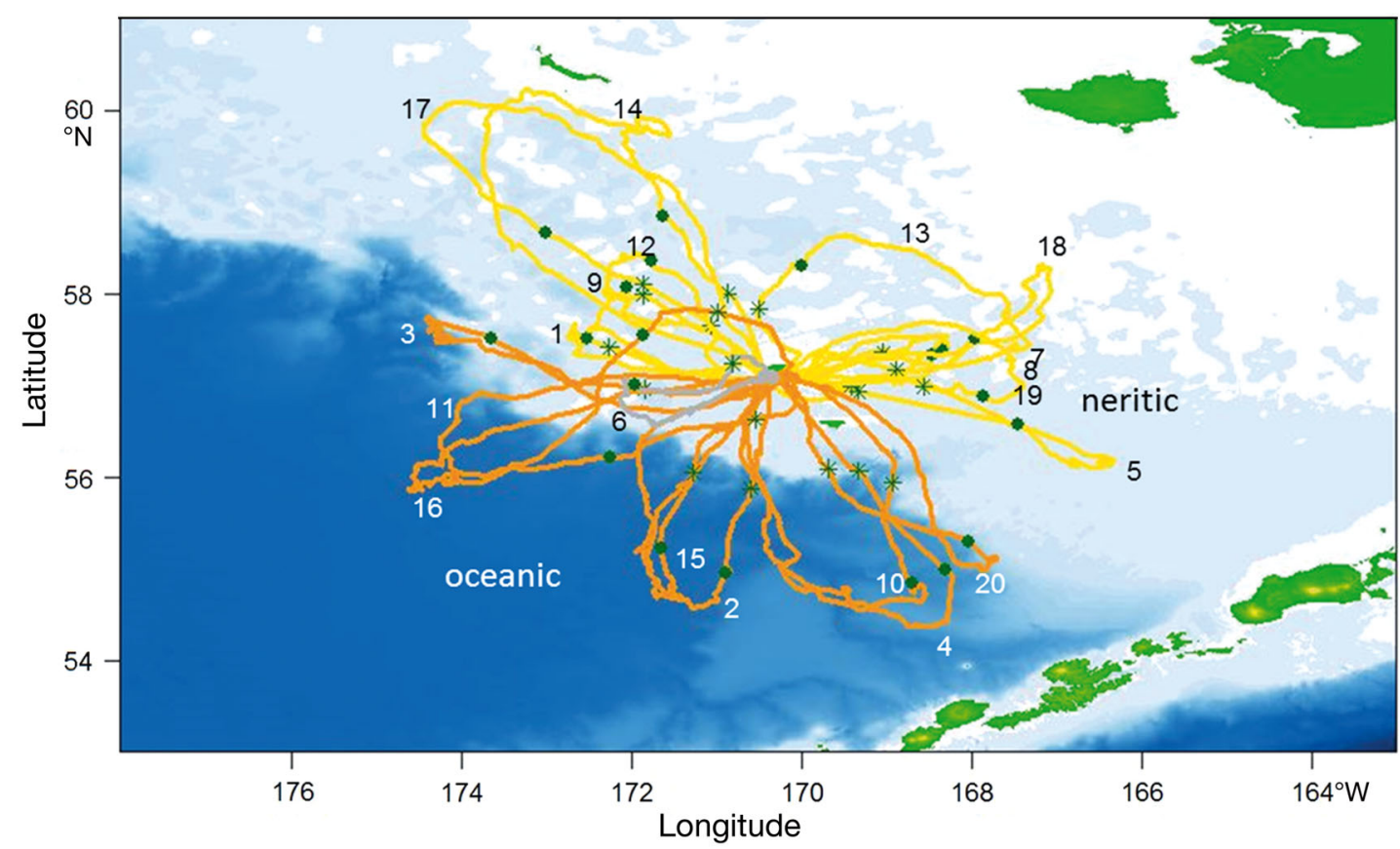

Fig. 3. Foraging tracks of 20 lactating northern fur seal females breeding on Reef Rookery on St. Paul Island, and foraging in the Bering Sea, Alaska. Tracks are derived from Fastloc GPS locations. Numbers next to tracks are ID numbers of individual seals. Yellow tracks show the females that stayed foraging in neritic waters $(n=11)$ and orange ones the females that went foraging in oceanic waters $(\mathrm{n}=8$ ). The grey track represents the foraging track of Seal \#6 (outlier). Green dots and stars indicate the time points $48 \mathrm{~h}$ and $24 \mathrm{~h}$, respectively, prior to landing

\section{Foraging locations and behaviours}

The female northern fur seals weighed on average $37.9 \pm 1.3 \mathrm{~kg}$ prior to departure (range 30.8 to $55.6 \mathrm{~kg}$, $\mathrm{n}=20$ ), and gained $1.1 \pm 3.0 \mathrm{~kg}$ during their single foraging trips (a $3.5 \pm 1.8 \%$ gain in body mass). The average foraging trip was $\sim 750 \pm 50 \mathrm{~km}$ (range 391 to $1200 \mathrm{~km}$ ) and lasted $7.9 \pm 2.2 \mathrm{~d}$ (range 4.2 to $12.1 \mathrm{~d}$ ). The females travelled widely, but 12 of the 20 stayed on the Bering Sea shelf (hereafter called neritic females), while the remaining 8 went off the shelf into more oceanic waters (hereafter called oceanic females) (Fig. 3). Oceanic females spent on average $2.5 \mathrm{~d}$ longer at sea and traveled $200 \mathrm{~km}$ more than neritic females $(9.7 \pm 1.8 \mathrm{~d}$ and $892 \pm 144 \mathrm{~km}$ versus $7.1 \pm 2.4 \mathrm{~d}$ and $655 \pm 218 \mathrm{~km}$, respectively; $t$-test, $\mathrm{p}<0.011$ in both cases).

Neritic females dived benthically $(15.2 \pm 2.6 \%$ of all dives) and occasionally foraged during the day, while females foraging in oceanic waters off the shelf rarely performed benthic dives $(2.2 \pm 0.4 \%$ in total including none when off the shelf) and were nocturnal divers. Oceanic females also performed significantly more foraging dives $(2526 \pm 155$ dives $)$ than the neritic females $(1648 \pm 2526$ dives; $\mathrm{p}<0.001)$, but the dives were on average shallower (depth $16 \pm 2 \mathrm{~m}$ versus $28 \pm 4 \mathrm{~m}$ for oceanic and neritic females, respectively; $\mathrm{p}=0.011)$ and lasted half the time $(42 \pm$ $6 \mathrm{~s}$ versus $84 \pm 10 \mathrm{~s}$ for oceanic and neritic females, respectively; $\mathrm{p}<0.001$ ). Overall, oceanic females also spent $\sim 10 \%$ less time diving $(24.7 \pm 0.8 \%)$ than neritic females $(33.1 \pm 3.1 \%$; $<<0.02)$.

\section{Stable isotopes}

Isotopic values from plasma collected before the seals' foraging trip had average $\delta^{13} \mathrm{C}$ values of -19.1 $\pm 0.5 \%$ o $(-18.8 \pm 0.4 \%$ for the neritic group and -19.5 $\pm 0.2 \%$ for the oceanic group) and average $\delta^{15} \mathrm{~N}$ values of $16.0 \pm 1.3 \%$ o $(17.0 \pm 0.8 \%$ for the neritic group and $14.9 \pm 0.6 \%$ for the oceanic group). The plasma $\delta^{13} \mathrm{C}$ and $\delta^{15} \mathrm{~N}$ values collected after the foraging trips, indicative of foraging behaviours during the foraging trip over which seals were tracked, were $-19.1 \pm 0.5 \%$ for $\delta^{13} \mathrm{C}$ and $16.2 \pm 1.4 \%$ or $\delta^{15} \mathrm{~N}$ for lactating females breeding on St. Paul Island. There were 2 distinct $\delta^{13} \mathrm{C}$ and $\delta^{15} \mathrm{~N}$ clusters within our 20 females, one centered around $-18.8 \pm 0.3 \%$ and 17.3 $\pm 0.6 \%$, respectively and the other centered around $-19.6 \pm 0.1 \%$ and $14.9 \pm 0.5 \%$, respectively. The former cluster corresponded to females foraging in neritic waters and the latter to females foraging in oceanic waters; the differences between the clusters 


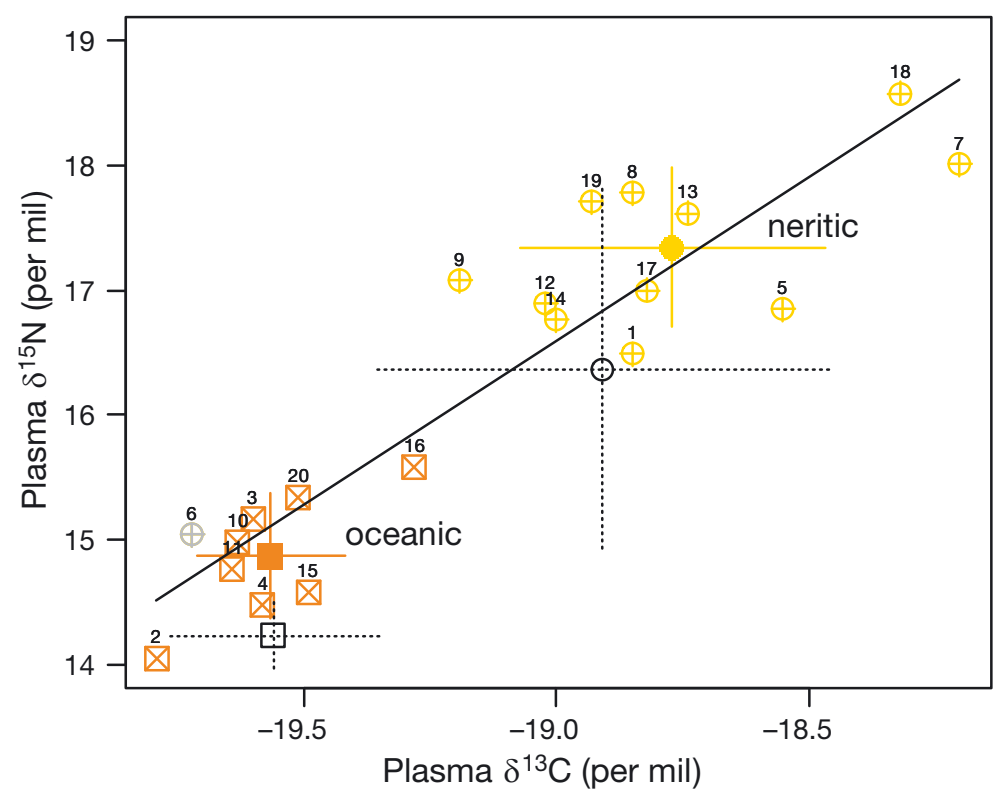

Fig. 4. Plasma $\delta^{13} \mathrm{C}$ and $\delta^{15} \mathrm{~N}$ values of 20 adult northern fur seal females breeding on St. Paul Island, Bering Sea from blood samples taken after their foraging trip at sea. Crossed yellow circles represent females foraging in neritic waters $(\mathrm{n}=11)$ and crossed orange squares those foraging in oceanic waters $(n=8)$, with individual IDs shown next to the respective data point. The closed yellow circle and orange square are averages for neritic and oceanic groups (excluding Seal \#6 in grey), respectively; error bars show $\pm \mathrm{SD}$. The plain line shows the correlation between the isotopic values. The black circle and square represent $\delta^{13} \mathrm{C}$ and $\delta^{15} \mathrm{~N}$ values $( \pm \mathrm{SD})$ for adult fur seals breeding on St Paul Island and on Bogoslof Island respectively from Fig. 3 in Zeppelin \& Orr (2010). One female (Seal \#6, grey crossed dot) that remained on the shelf to forage nevertheless showed isotopic values corresponding to oceanic foraging. She was the only 'neritic' female that went foraging SW towards the shelf. Even though she did not seem to go foraging in the basin, she might have stayed around the shelf break and consumed basin prey advected from oceanic waters. Raw data for individual fur seals can be found in Table S2 in the Supplement

values in RBC collected before the foraging trip to isotopic values in plasma collected after the foraging trip are also significantly correlated and not different from 1 (both $\mathrm{p}<0.001$; $95 \%$ CI values were $0.61-1.44$ and $0.34-1.08$ for $\delta^{13} \mathrm{C}$ and $\delta^{15} \mathrm{~N}$ slopes, respectively, Fig. 6A,B), but were not as strongly correlated as on the shorter term (Fig. 5). The significantly lower $\delta^{13} \mathrm{C}$ or $\delta^{15} \mathrm{~N}$ values in RBC compared to isotopic values measured in plasma is due to a tissue-dependant difference (i.e. RBC versus plasma; Kurle 2002, Orr et al. 2008). The previously mentioned outlier (Seal \#6) remained an oceanic forager over the short- (Fig. 5) and mid-term (Fig. 6).

\section{DISCUSSION}

To our knowledge, this study is the first to use a combination of 4 complementary methods to obtain a more complete and accurate depiction of the diet of a pinniped. Pairing results from the traditional identification of hard-part remains in scats with the newly-developed DNAmetabarcoding method provided a more diverse and complete picture of northern fur seals' diet in the Bering Sea, and allowed identification of 2 distinct diets within the population. These distinct diets were confirmed by stable isotope

were significant for both isotopes ( $\mathrm{p}<0.0001$; Fig. 4, Table S2). We noticed an outlier in Seal \#6 that remained foraging on the shelf (although towards the shelf break southeast of St. Paul Island) but nevertheless showed isotopic values corresponding to those of oceanic foragers (Figs. 4-6). None of the isotopic values in plasma collected before and after the seals' foraging trip differed significantly from each other ( $p>0.34$ ). In addition, correlations between plasma values collected before and after trips were highly significant ( $\mathrm{p}<0.001$ for $\delta^{13} \mathrm{C}$ and $\delta^{15} \mathrm{~N}$ ). $95 \% \mathrm{CI}$ values were $0.58-1$ and $0.63-1.16$ for $\delta^{13} \mathrm{C}$ and $\delta^{15} \mathrm{~N}$, respectively (Fig. 5A,B), indicating slopes not significantly different from 1.

Isotopic values in $\mathrm{RBC}$ collected before the foraging trip were $-19.4 \pm 0.4 \%$ for $\delta^{13} \mathrm{C}(-19.2 \pm 0.3 \%$ o for neritic females and $-19.7 \pm 0.3 \%$ for oceanic females), and $15.0 \pm 1.6 \%$ or for $\delta^{15} \mathrm{~N}(15.2 \pm 0.7 \%$ for neritic females and $14.0 \pm 1.5 \%$ or oceanic females). Isotopic analyses and attributed to different foraging strategies based on location data from biologgers. Together, the methods showed short- and mid-term specializations of individuals that either (1) foraged in neritic waters mostly on gadids, cephalopods, forage fish, hexagrammids and flatfish, or (2) foraged in oceanic waters on gadids, cephalopods, mesopelagic fish and salmons. Integrating methods at different temporal scales demonstrates that the oceanic foraging strategy and diet could have been underestimated if scats had not been analyzed concomitantly with stable isotopes and telemetry data ( 1 to $2 \mathrm{wk}$ and up to 2 mo temporal windows, respectively). Consequently, only the combination of these 4 methods allowed us to draw a more complete and ecologically accurate picture of the diets of lactating females within the breeding population on St. Paul Island, and to determine that estimates of diet for the population can be reflected at the individual level at different spatial and temporal scales. 


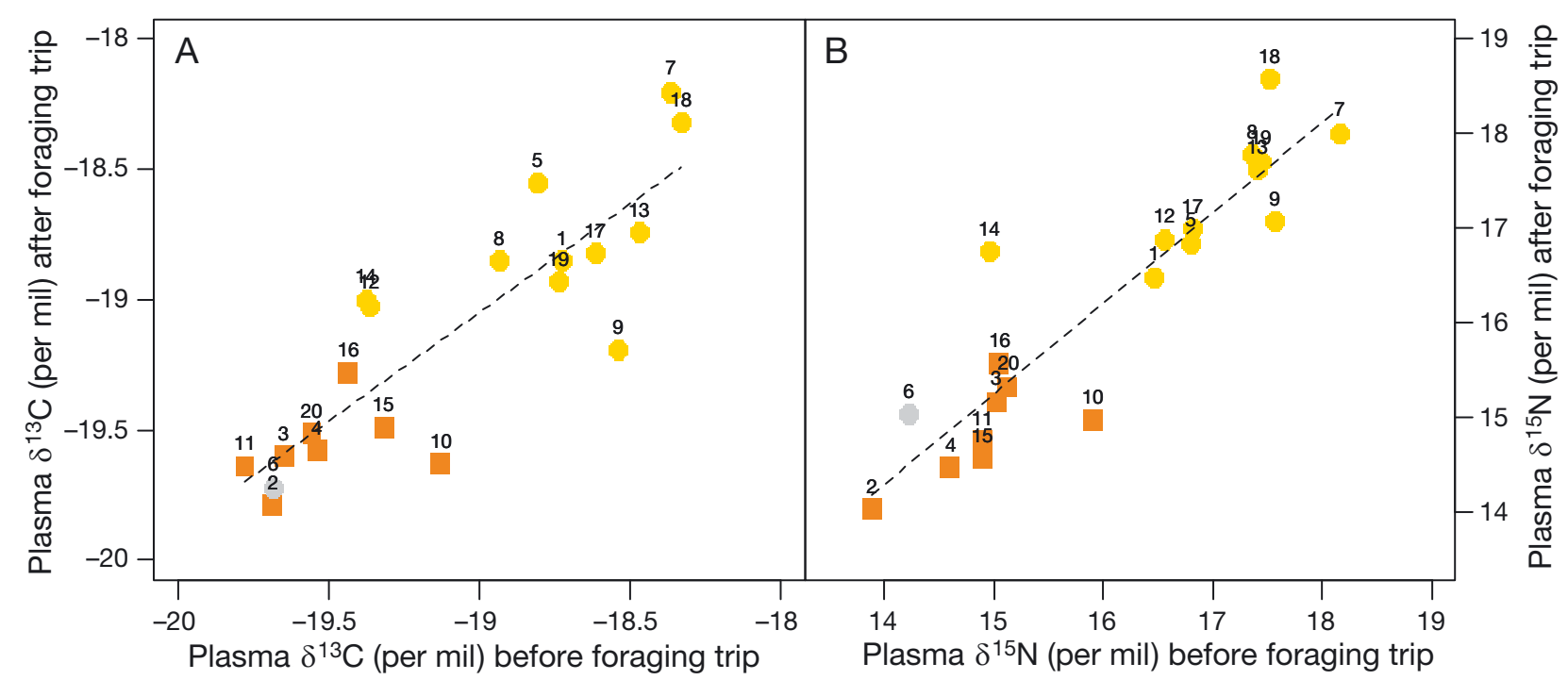

Fig. 5. Comparison of plasma values for (A) $\delta^{13} \mathrm{C}$ and (B) $\delta^{15} \mathrm{~N}$ in blood samples from 20 adult northern fur seal females breeding on St. Paul Island collected before versus after a foraging trip, indicative of short-term foraging specialization. Yellow dots are values for females foraging in neritic waters $(n=11)$ and the orange squares for females foraging in oceanic waters $(n=8)$ with individual IDs shown next to the respective data point. The grey dot represents an outlier seal (Seal \#6), which remained foraging on the shelf but showed oceanic isotopic values. Dashed lines show the linear regressions for each graph $\left(\delta^{13} \mathrm{C}\right.$ : slope $=0.83,95 \% \mathrm{CI}=0.58-1.08, \mathrm{R}^{2}=0.72 ; \delta^{15} \mathrm{~N}$ : slope $=0.95,95 \% \mathrm{CI}=0.63-1.16, \mathrm{R}^{2}=0.82$ )

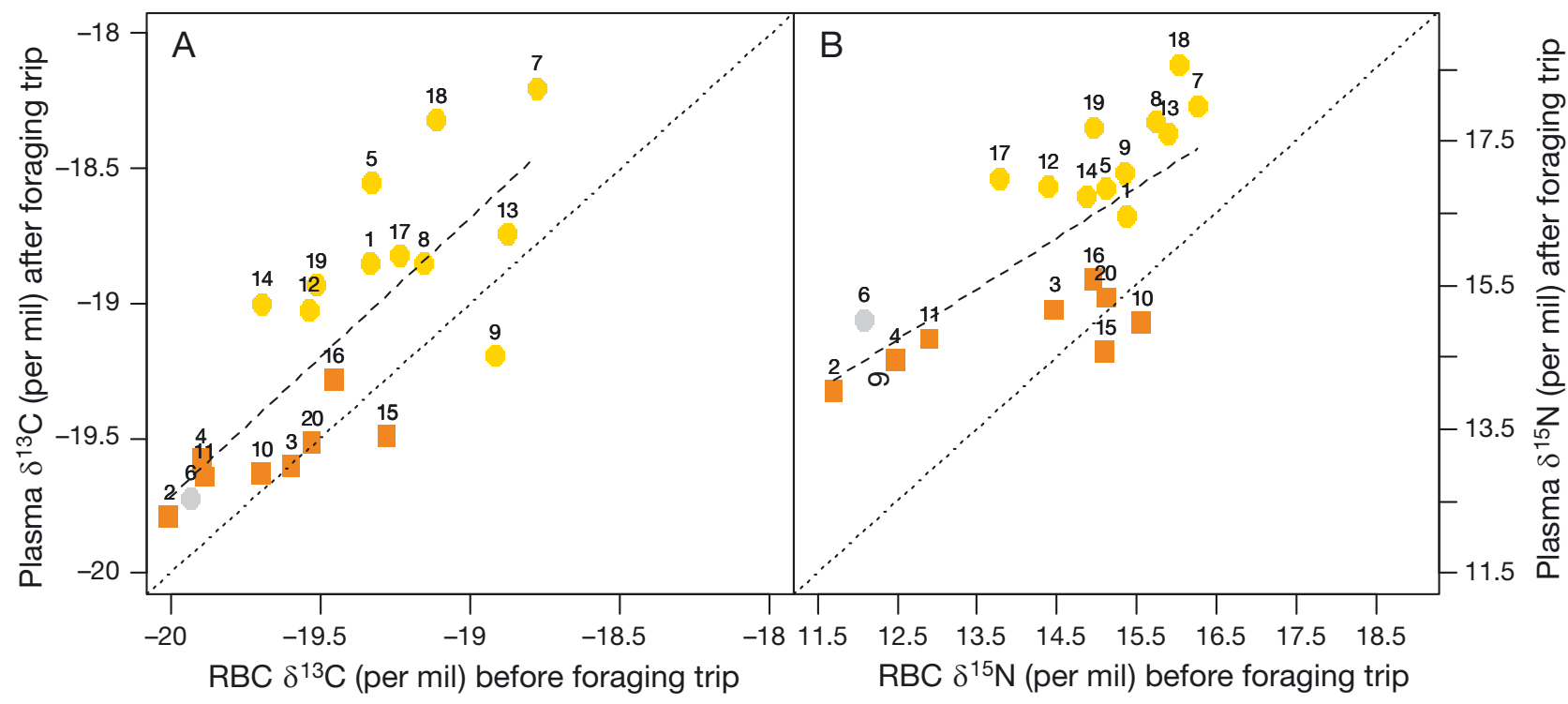

Fig. 6. Comparison of (A) $\delta^{13} \mathrm{C}$ and (B) $\delta^{15} \mathrm{~N}$ values in red blood cells (RBC) collected from 20 adult northern fur seal females breeding on St. Paul Island before a foraging trip and values in plasma collected after the foraging trip, indicative of mid-term foraging specialization ( 2 mo). Yellow dots represent females foraging in neritic waters $(\mathrm{n}=11)$ and the orange squares those foraging in oceanic waters $(n=8)$, with individual IDs shown next to the respective data point. The grey dot represents an outlier seal (Seal \#6), which remained foraging on the shelf but showed oceanic isotopic values. Dotted lines show the 1:1 lines, and dash lines show the linear regressions for each graph $\left(\delta^{13} \mathrm{C}\right.$ : slope $=1.02,95 \% \mathrm{CI}=0.61-1.44, \mathrm{R}^{2}=0.58 ; \delta^{15} \mathrm{~N}$ : slope $=0.71$, $95 \% \mathrm{CI}=0.34-1.08, \mathrm{R}^{2}=0.47$ ). It should be noted that the lower isotopic values in $\mathrm{RBC}$ compared to plasma are due to tissuespecific isotopic discrimination factors, i.e. differences in isotopic composition between a consumer's tissues and diet (Kurle 2002, Orr et al. 2008) 


\section{Scat-based diet identification: DNA and hard-part methods}

In this study, results from hard-parts and DNA analyses of prey in scats were in general agreement and confirmed that animals breeding on the Pribilof Islands mostly feed on a set of species comprising mainly walleye pollock, salmon, and forage fish including hexagrammids (Sinclair et al. 1994, Gudmundson et al. 2006, Waite et al. 2012). This consistency between the 2 methods was also shown for harbour seals and Steller sea lions at the population level (only species of minor importance differed between methods; Tollit et al. 2009), which indicates that major errors or omissions are unlikely in diet estimates. Compared to the more traditional method of hard-part identification, DNA-based methods have several advantages. They can detect prey to a finer taxonomic level than hard-parts analyses, and they perform particularly well for prey species that are morphologically identified by structures other than otoliths (Tollit et al. 2009). For example, our DNA analyses assigned occurrences of salmonids and cephalopods to the species level, while hardparts could only identify them at the family level (Fig. 1). In addition, use of the DNA-based method increased the number of prey occurrences detected by $\sim 25 \%$ compared to hard-part method alone, which helped to refine the richness (6 more species of fish detected) and composition of northern fur seals diet. This is in agreement with results on Steller sea lions ( 22\% more prey species identified using DNAbased methods; Tollit et al. 2009), but the degree of refinement achieved using DNA-based methods was much less than in studies on captive fur seals (Casper et al. 2007a). One of the possible reasons for this is that in our study scats were randomly collected on the rookery with no particular care given to their freshness. Desiccated organic matter in scats (and/or long term storage before analyses) results in degraded DNA that cannot be reliably amplified and assigned to specific prey (Tollit et al. 2009). The fact that freshness might have varied widely between scats could also explain, at least partly, the large differences in number of prey detected per scat.

Both methods were in agreement for most prey species in the diet except for cephalopods. Analysis of hard-parts gave estimates of the prevalence of cephalopods 8 times higher than the DNA-based method (Fig. 1, Table 1). Squid beaks are hard chitinous-fibrous structures resistant to digestion and are known to accumulate by hooking themselves onto the lining of the digestive system before being excreted (Bigg \& Fawcett 1985, Harvey \& Antonelis 1994). This 'pulse-like' and unpredictable excretion of beaks might create an artificially inflated detection of cephalopods (Tollit et al. 1997, Staniland 2002, Casper et al. 2007a). In contrast, the DNA meta-barcoding method may underestimate the occurrence of squids for 2 reasons: (1) cephalopods in this molecular method are amplified by a secondary PCR primer set which may be less efficient than the chordate marker in the multiplex PCR (Thomas et al. 2016); or (2) high water content prey species such as squids tend to have lower mtDNA density and be more completely broken down during the predator's digestive process, resulting in a lower probability of detection from scat organic matter (Thomas et al. 2014). The combined potential for overestimation from hard-parts and underestimation from DNA probably explains the 8-fold difference in detection between the 2 techniques.

Different digestion rates of prey components are just one of the limitations inherent in dietary determinations that rely on digested material, that result in biases in diet estimates (Cottrell et al. 1996, Thomas et al. 2014). However, combining results from the DNA and hard-parts techniques improves the accuracy of diet interpretation compared to either method alone: it increases recognition of prey richness and suppresses method-specific biases (Casper et al. 2007b, Tollit et al. 2009). For example, the relative importance of cephalopods in the diet (SSFO) was estimated as $8.9 \%$ using the combined method, less than suggested by the hard-part method (known to overestimate these prey) and more than the DNA method (likely to underestimate these prey).

Out of the 146 combined prey occurrences, 39\% were identified by the DNA-based method only, $\sim 18 \%$ by the hard-part method only, and $43 \%$ with both. Despite this uneven contribution to the combined dataset, biases of the DNA method were not found to have a greater effect on the interpretation of final results compared to the biases inherent in the hard-parts method (Casper et al. 2007b, Tollit et al. 2009). The more complete and complex data sets obtained from combining results from both methods also enable more robust estimations of prey associations in scats. Cluster analyses on the combined dataset revealed 2 main diets in female northern fur seals at Reef Rookery, one associated with oceanic prey (mesopelagic fish, salmon), and one associated with neritic prey (forage fish including hexagrammids and flatfish). These 2 diets both had walleye pollock as the predominant prey, as well as significant cephalopod components (Fig. 2). It is interesting to note that 
the statistical power was too low to be reliably performed on results from either technique alone.

To conclude, combining scat-based methods helps provide a more complete and less biased picture of the diet composition of northern fur seals than using either method alone. As such, the increased diet richness and thus statistical power allows deeper and finer interpretation of the prey associations and thus can help tease apart different diets that might exist within the population. While DNA-based analyses provide a finer picture of diet composition than hardparts methods, they do not allow us to follow the flow of energy from prey to predators, as this requires information on the size and age class of ingested prey. This can only be obtained from the lengths of sagittal otoliths, squid beaks or other hard-part remains in scats (Paul \& Paul 1999, Tollit et al. 2004). Consequently, integrating both morphological and molecular-based data improves the qualitative and quantitative information about diets, and contributes to a better understanding of the trophic relations and foraging efficiencies of northern fur seals.

\section{Biologging, stable isotopes and prey associations reveal 2 foraging strategies}

Scat-based methods provide useful information about diet composition of free-ranging animals. However, they are only representative of what animals consumed over a short 10 to $48 \mathrm{~h}$ period before they returned to land (Orr \& Harvey 2001, Staniland 2002, Casper et al. 2007a). Longer timescales are sometimes equally or more relevant in ecological studies for understanding foraging behaviours and efficiencies, as well as the relationships between prey fields and predators. Analyses of stable isotopes can provide this information that cannot be obtained using the aforementioned methods.

Plasma isotopic turnover time is considered to be $\sim 1$ to 2 wk (Kurle 2002, Orr et al. 2008), so we assumed that plasma $\delta^{13} \mathrm{C}$ and $\delta^{15} \mathrm{~N}$ values in this study reflected the foraging strategy during the foraging trip we monitored (Jaeger et al. 2010). Our stable isotope results showed that female fur seals foraged at 2 different locations $\left(\delta^{13} \mathrm{C}\right)$ where they fed on different prey $\left(\delta^{15} \mathrm{~N}\right)$ (Fig. 4). By combining this data with information on foraging tracks (Fig. 3), it was shown that these groups corresponded to (1) females foraging in oceanic waters on pelagic prey, and (2) females foraging in a more nearshore/benthic system. The females foraging on the shelf $(\sim 100 \mathrm{~m}$ depth) had access to the benthos and its associated prey (that have inherently higher baseline $\delta^{13} \mathrm{C}$ and $\delta^{15} \mathrm{~N}$ values), which was not accessible to fur seals feeding in oceanic waters $(>1000 \mathrm{~m})$. Females foraging over the shelf dived deeper (sometimes to the bottom) for longer times overall compared to the strictly pelagic, shallow and short dives of the oceanic females. Such differences in neritic and oceanic foraging behaviours have been previously noted for females breeding on Reef Rookery (Gentry 1998, Nordstrom et al. 2013).

Our neritic isotopic values did not differ significantly from previous measurements on females from the Pribilof Islands, i.e. approximate values of $-18.9 \pm$ $0.5 \%$ for $\delta^{13} \mathrm{C}$ and $16.4 \pm 1.4 \%$ o for $\delta^{15} \mathrm{~N}$ reported by Zeppelin \& Orr (2010) (shown in black on Fig. 4), and $17.3 \pm 0.1 \%$ o for $\delta^{15} \mathrm{~N}$ in Kurle \& Worthy (2001). It is noteworthy that female fur seals foraging in oceanic waters had $\delta^{13} \mathrm{C}$ and $\delta^{15} \mathrm{~N}$ values that were similar to females foraging off Bogoslof Island $\left(53^{\circ} 55^{\prime} \mathrm{N}\right.$, $168^{\circ} 2^{\prime} \mathrm{W}$ ) north of the Aleutian Islands within the Bering Sea deep basin (Zeppelin \& Orr 2010). This suggests that the oceanic fur seals from the Reef Rookery on the Pribilof Islands have similar diets and habitats to fur seals breeding on Bogoslof Island.

Diet composition estimated from scats collected on Bogoslof Island indicate that fur seals breeding there consume mid-water prey in oceanic domains consisting mostly of mesopelagic fish and gonatid squid (both 73.2\% FO in Zeppelin \& Orr (2010) and $>75 \%$ FO in a study by A. W. Trites (unpubl. data)), and to a lesser extent myctophids (17.1\% FO; Zeppelin \& Orr 2010) and salmon ( 15\% FO; A.W. Trites unpubl. data). Fewer than $10 \%$ of the scats in both studies contained walleye pollock, which contrasts with the high prevalence of walleye pollock in the diets identified in the present study for Pribilof Island seals, at least those feeding on the shelf. In all likelihood, females from the Pribilof Islands that travelled off-shelf consumed a similar diet to those breeding on Bogoslof Island, and all walleye pollock consumed by Pribilof seals were caught on the shelf. Such a possibility is consistent with the cluster analyses of prey associations showing one cluster of cephalopods, mesopelagic and salmon species associated with pelagic mid-water oceanic ecosystems, and a second cluster of cephalopods, flatfish, hexagrammids, forage fish that are associated with shelf systems (Fig. 2).

Interestingly, $100 \%$ of the scats that contained mesopelagic species also contained salmonids (although salmonids were not exclusively associated with mesopelagic fish, such as northern smoothtongue or northern lampfish), but the scats in the 
cluster corresponding to a diet of mesopelagic fish and salmonids represented only $\sim 6 \%$ of the total number of scats. If we consider this cluster representative of the diet of the oceanic females, then while $40 \%$ of our tagged animals foraged in oceanic waters only $6 \%$ of the scats collected represented their diet. This means that this foraging strategy is under-represented in the scats collected on St. Paul Island, such that the dietary estimation results (from scats) would have to be corrected by a factor of 8 to reach the same proportion as the one unveiled by telemetry and stable isotope data. This is not surprising knowing that scats are indicative of food ingested within the previous 10 to $48 \mathrm{~h}$ in fur seals (Bigg 1981, Casper et al. 2007a), and that females foraging in oceanic waters travel for $\sim 150 \mathrm{~km}$ (a travel time of $\sim 24 \mathrm{~h}$ and longer) to return to land. The likelihood that they defecate the remains of meals eaten off the shelf before reaching the shore is consequently greater than for females foraging in waters surrounding the rookery.

The slightly higher $\delta^{15} \mathrm{~N}$ value for oceanic females from St. Paul compared to the Bogoslof females (Fig. 4) likely reflects greater amounts of walleye pollock in the St. Paul diet. Our cluster analysis shows an association of gadids with the 2 clusters (Fig. 2). This indicates that even if the pollock is less strongly associated with the mesopelagic and salmon cluster (i.e. longer distance between pollock and cluster of oceanic diet compared to cluster of neritic diet on Fig. 2), it is still ubiquitous in scats containing these prey. Fur seals are generalist opportunistic feeders and will consume fish species present in their foraging/diving areas. As such, dive profiles of the oceanic females we tracked indicate that they also foraged in these relatively shallow waters while transiting from and back to the colony, and thus likely consumed gadids and other shelf-associated prey during their transit over the shelf to and from their rookery. As Bogoslof Island is not located on the Bering Sea shelf, females leaving the Bogoslof rookery are directly foraging in the deep basin without the opportunity to feed on shelf-associated prey during their transit.

Carbon and nitrogen isotopic values in plasma before and after the foraging trip confirmed that there were 2 main foraging strategies amongst individual females from St. Paul Island. The clear correlations between isotopes before and after the foraging trip also indicates that overall female fur seals maintain their foraging strategy, i.e. specialize in foraging location and trophic levels over the short term ( 2 to $4 \mathrm{wk}$ ), which is consistent with previous findings (Call et al. 2008). RBC isotopic values showed that the tendency to maintain foraging strategies remains true over a $\sim 2$ mo or longer period of time, which indicates a temporal consistency of specialization among individuals during the breeding season (however, not as marked as over a shorter timeframe, Fig. 5). Some females might change their foraging strategies over a longer period of time or RBC isotopic values might partially reflect the diet and feeding locations during the spring migration through the Pacific Ocean to the Bering Sea (Antonelis 1996) (i.e. feeding at a lower trophic level and/or in more offshore/pelagic/low latitude locations than during the foraging trip we studied). This might also explain why the differences in isotope values between plasma and RBC are larger for neritic females than for oceanic ones as the habitat and prey assemblage in northern Pacific Ocean are likely more similar to oceanic than to neritic habitats in the Bering Sea. Nevertheless, overall our results indicated an individual specialization in feeding and foraging within a given breeding season. As increased population density tends to increase intra-specific competition and individual specialization (Kernaléguen et al. 2015), the large numbers of fur seals gathered on breeding beaches on the Pribilof Islands during the breeding season is likely responsible for the spatial and dietary partitioning identified in this study. Ultimately, if profitability of one strategy is consistently greater than the other, maternal investment in pups and thus reproductive success of individuals might be differentially affected.

\section{Conclusion}

Our results show that DNA-based and hard-partsbased methods are complementary and together provide a refined estimate of prey ingested by northern fur seal females. However, although scat-based methods of diet determination provide essential qualitative and quantitative information on prey ingested, they only represent a snapshot of what animals in the population have eaten in the last $48 \mathrm{~h}$. They might underestimate some dietary specializations, or not be representative of the diet of individuals on the longer term. By integrating cluster analysis of prey species co-occurring in scats with differences in foraging habitats and dietary habits from stable isotopes and biologging data, it was possible to confidently identify distinct diets and feeding strategies in northern fur seals breeding on the Pribilof Islands. Individuals in a population are not ecologically equivalent, and populations of generalist feeders are 
often made up of subsets of specialist individuals. In addition, intra-population comparisons between breeding colonies associated with different diets, foraging habitats and population trends, such as between seals breeding on the Pribilof Islands and Bogoslof Island, can add valuable insights into the interpretation of both individual feeding behaviours and dietary habits and population trends. Consequently, combining complementary methods at different spatial and temporal scale to tease apart individual diet within the context of foraging ecology has important consequences for studies seeking to describe energetics, foraging efficiency and ultimately fitness of individuals, especially in declining populations such as northern fur seals.

Acknowledgements. We thank Alistair Baylis, Rachel Orben, John Arnould and Michelle Barbieri for their help in collecting the data. We also thank the Plateforme de Spectrométrie Isotopique de LIENSs at the Université de la Rochelle, France for their help analysing the stable isotopes, and the Washington Department of Fish and Wildlife Molecular Genetics lab for their help analysing DNA in scats. Funding for this project came from the Canadian National Science and Engineering Research Council and the North Pacific Research Board.

\section{LITERATURE CITED}

Altschul SF, Gish W, Miller W, Myers EW, Lipman DJ (1990) Basic local alignment search tool. J Mol Biol 215:403-410

Anderson PJ, Piatt JF (1999) Community reorganization in the Gulf of Alaska following ocean climate regime shift. Mar Ecol Prog Ser 189:117-123

Anderson PJ, Blackburn JE, Johnson BA (1997) Declines of forage species in the Gulf of Alaska, 1972-1995, as an indicator of regime shift. In: Forage fishes in marine ecosystems. Alaska Sea Grant, University of Alaska Fairbanks, Fairbanks, AK, p 531-543

Antonelis GA (1996) Migration studies of northern fur seals. NWAFSC Quarterly Report (Apr-June). Alaska Fisheries Science Center, Seattle

Antonelis GA, Sinclair EH, Ream RR, Robson BW (1997) Inter-island variability in the diet of female northern fur seals (Callorhinus ursinus) in the Bering Sea. J Zool (Lond) 242:435-451

Arim M, Naya DE (2003) Pinniped diets inferred from scats: analysis of biases in prey occurrence. Can J Zool 81: $67-73$

Authier M, Dragon AC, Richard P, Cherel Y, Guinet C (2012) $\mathrm{O}^{\prime}$ mother where wert thou? Maternal strategies in the southern elephant seal: a stable isotope investigation. Proc R Soc B 279:2681-2690

Bigg MA (1981) Digestion rates of herring (Clupea harengus pallasi) and squid (Loligo opalescens) in northern fur seals. Proc 24th Annual Meeting of the Standing Scientific Committee, North Pacific Fur Seal Commission, Tokyo, p 1-12

Bigg MA, Fawcett I (1985) Two biases in diet determination of northern fur seals (Callorhinus ursinus). In: Beddington JR, Beverton RJH, Lavigne DM (eds) Marine mammals and fisheries. George Allen and Unwin Publishing, London, p 284-291

* Burton RK, Koch PL (1999) Isotopic tracking of foraging and long-distance migration in northeastern Pacific pinnipeds. Oecologia 119:578-585

Call KA, Ream RR, Johnson D, Sterling JT, Towell RG (2008) Foraging route tactics and site fidelity of adult female northern fur seal (Callorhinus ursinus) around the Pribilof Islands. Deep Sea Res II 55:1883-1896

* Caporaso JG, Kuczynski J, Stombaugh J, Bittinger K and others (2010) QIIME allows analysis of high-throughput community sequencing data. Nat Methods 7:335-336

* Carreon-Martinez L, Heath DD (2010) Revolution in food web analysis and trophic ecology: diet analysis by DNA and stable isotope analysis. Mol Ecol 19:25-27

* Casper RM, Jarman SN, Deagle BE, Gales NJ, Hindell MA (2007a) Detecting prey from DNA in predator scats: a comparison with morphological analysis, using Arctocephalus seals fed a known diet. J Exp Mar Biol Ecol 347: 144-154

* Casper RM, Jarman SN, Gales N, Hindell M (2007b) Combining DNA and morphological analyses of faecal samples improves insight into trophic interactions: a case study using a generalist predator. Mar Biol 152:815-825

* Cherel Y, Hobson KA, Weimerskirch H (2005) Using stable isotopes to study resource acquisition and allocation in procellariiform seabirds. Oecologia 145:533-540

* Cherel Y, Hobson KA, Guinet C, Vanpe C (2007) Stable isotopes document seasonal changes in trophic niches and winter foraging individual specialization in diving predators from the Southern Ocean. J Anim Ecol 76:826-836

* Cherel Y, Quillfeldt P, Delord K, Weimerskirch H (2016) Combination of at-sea activity, geolocation and feather stable isotopes documents where and when seabirds molt. Front Ecol Evol 4:3

Cottrell PE, Trites AW, Miller EH (1996) Assessing the use of hard parts in faeces to identify harbour seal prey: results of captive-feeding trials. Can J Zool 74:875-880

Cristescu ME (2014) From barcoding single individuals to metabarcoding biological communities: towards an integrative approach to the study of global biodiversity. Trends Ecol Evol 29:566-571

* Deagle BE, Kirkwood R, Jarman SN (2009) Analysis of Australian fur seal diet by pyrosequencing prey DNA in faeces. Mol Ecol 18:2022-2038

* Deagle B, Chiaradia A, McInnes J, Jarman S (2010) Pyrosequencing faecal DNA to determine diet of little penguins: Is what goes in what comes out? Conserv Genet 11:2039-2048

Edgar RC (2010) Search and clustering orders of magnitude faster than BLAST. Bioinformatics 26:2460-2461

France RL (1995) Carbon-13 enrichment in benthic compared to planktonic algae: food web implications. Mar Ecol Prog Ser 124:307-312

Gentry RL (1998) Behavior and ecology of the northern fur seal. Princeton University Press, Princeton, NJ

Gentry RL, Kooyman GL (eds) (1986) Fur seals: maternal strategies on land and at sea. Princeton University Press, Princeton, NJ

Goodman LA, Kruskal WH (1954) Measures of association for cross classifications. J Am Stat Assoc 49:732-764

Gudmundson CJ, Zeppelin TK, Ream RR (2003) Comparison of two methodologies for determining diet in northern fur 
seals (Callorhinus ursinus). National Marine Fisheries Service, Seattle, WA

Gudmundson CJ, Zeppelin TK, Ream RR (2006) Application of two methods for determining diet of northern fur seals (Callorhinus ursinus). Fish Bull 104:445-455

Harvey JT, Antonelis GA (1994) Biases associated with nonlethal methods of determining the diet of northern elephant seals. Mar Mamm Sci 10:178-187

*Hobson KA, Welch HE (1992) Determination of trophic relationships within a high Arctic marine food web using stable-isotope analysis. Mar Ecol Prog Ser 84:9-18

Jaeger A, Lecomte VJ, Weimerskirch H, Richard P, Cherel Y (2010) Seabird satellite tracking validates the use of latitudinal isoscapes to depict predators' foraging areas in the Southern Ocean. Rapid Commun Mass Spectrom 24: 3456-3460

Kelly JF (2000) Stable isotopes of carbon and nitrogen in the study of avian and mammalian trophic ecology. Can J Zool 78:1-27

Kernaléguen L, Arnould JPY, Guinet C, Cherel Y (2015) Determinants of individual foraging specialization in large marine vertebrates, the Antarctic and subantarctic fur seals. J Anim Ecol 84:1081-1091

Kuhn CE, Ream RR, Sterling JT, Thomason JR, Towell RG (2014) Spatial segregation and the influence of habitat on the foraging behavior of northern fur seals (Callorhinus ursinus). Can J Zool 92:861-873

Kurle CM (2002) Stable-isotope ratios of blood components from captive northern fur seals (Callorhinus ursinus) and their diet: applications for studying the foraging ecology of wild otariids. Can J Zool 80:902-909

Kurle CM, Worthy GAJ (2001) Stable isotope assessment of temporal and geographic differences in feeding ecology of northern fur seals (Callorhinus ursinus) and their prey. Oecologia 126:254-265

Newsome SD, Clementz MT, Koch PL (2010) Using stable isotope biogeochemistry to study marine mammal ecology. Mar Mamm Sci 26:509-572

Nordstrom CA, Battaile BC, Cotte C, Trites W (2013) Foraging locations of lactating fur seals are structured by thermocline depths and mesoscale fronts in the eastern Bering Sea. Deep-Sea Res II 88-89:78-96

Olesiuk PF (1993) Annual prey consumption by harbor seals (Phoca vitulina) in the Strait of Georgia, British Columbia. Fish Bull 91:491-515

Olesiuk PF, Bigg MA, Ellis GM, Crockford SJ, Wigen RJ (1990) An assessment of the feeding habits of harbour seals (Phoca vitulina) in the Strait of Georgia, British Columbia, based on scat analysis. Department of Fisheries and Oceans, Nanaimo, BC

Orr AJ, Harvey JT (2001) Quantifying errors associated with using fecal samples to determine the diet of the California sea lion (Zalophus californianus). Can J Zool 79: 1080-1087

Orr AJ, Newsome SD, DeLong RL (2008) Variation in stable carbon and nitrogen isotope values from multiple tissues of California sea lions (Zalophus californianus). In: Damiani CC, Garcelon DK (eds) Proc Seventh California Islands Symp, Oxnard, CA. Institute for Wildlife Studies, Arcata, CA

Paine RT (1980) Food webs: linkage, interaction strength and community infrastructure. J Anim Ecol 49:666-685

Paul AJ, Paul JM (1999) Interannual and regional variations in body length, weight and energy content of age-0 Pacific herring from Prince William Sound, Alaska. J Fish
Biol 54:996-1001

Perez MA, Bigg MA (1986) Diet of northern fur seals, Callorhinus ursinus, off western North America. Fish Bull 84: 957-971

Pierce GJ, Boyle PR (1991) A review of methods for diet analysis in piscivorous marine mammals. Oceanogr Mar Biol Annu Rev 29:409-486

Raboy BE, Dietz JM (2004) Diet, foraging, and use of space in wild golden-headed lion tamarins. Am J Primatol 63:1-15

Robson BW, Goebel ME, Baker JD, Ream RR and others (2004) Separation of foraging habitat among breeding sites of a colonial marine predator, the northern fur seal (Callorhinus ursinus). Can J Zool 82:20-29

Romano MD, Piatt JF, Roby DD (2006) Testing the junk-food hypothesis on marine birds: effects of prey type on growth and development. Waterbirds 29:407-414

Rosen DAS, Trites AW (2000) Assessing the role of nutritional stress in the decline of wild populations: a Steller case of scientific sleuthing. In: Baer CLK (ed) Proc Third Comparative Nutrition Society Symp, Pacific Grove, CA, 4-9 Aug 2000, p 182-186

* Schnell IB, Bohmann K, Gilbert MTP (2015) Tag jumps illuminated-reducing sequence-to-sample misidentifications in metabarcoding studies. Mol Ecol Resour 15: 1289-1303

Sinclair EH, Loughlin TR, Pearcy W (1994) Prey selection by northern fur seals (Callorhinus ursinus) in the eastern Bering Sea. Fish Bull 92:132-156

Sinclair EH, Vlietstra LS, Johnson DS, Zeppelin TK and others (2008) Patterns in prey use among fur seals and seabirds in the Pribilof Islands. Deep Sea Res II 55: 1897-1918

Sinnott RW (1984) Virtues of the Haversine. Sky Telescope 68:159

* Staniland IJ (2002) Investigating the biases in the use of hard prey remains to identify diet composition using Antarctic fur seals (Arctocephalus gazella) in captive feeding trials. Mar Mamm Sci 18:223-243

Stephens DW, Krebs JR (1986) Foraging theory. Princeton University Press, Princeton, NJ

Thiebot JB, Bost CA, Dehnhard N, Demongin L and others (2015) Mates but not sexes differ in migratory niche in a monogamous penguin species. Biol Lett 11:20150429

* Thomas AC, Jarman SN, Haman KH, Trites AW, Deagle BE (2014) Improving accuracy of DNA diet estimates using food tissue control materials and an evaluation of proxies for digestion bias. Mol Ecol 23:3706-3718

* Thomas AC, Deagle BE, Eveson JP, Harsch CH, Trites AW (2016) Quantitative DNA metabarcoding: improved estimates of species proportional biomass using correction factors derived from control material. Mol Ecol Resour 16:714-726

* Thomas AC, Nelson BW, Lance MM, Deagle BE, Trites AW (2017) Harbour seals target juvenile salmon of conservation concern. Can J Fish Aquat Sci 74:907-921

Tollit DJ, Steward MJ, Thompson PM, Pierce GJ, Santos MB, Hughes S (1997) Species and size differences in the digestion of otoliths and beaks: implications for estimates of pinniped diet composition. Can J Fish Aquat Sci 54: 105-119

* Tollit DJ, Wong M, Winship AJ, Rosen DAS, Trites AW (2003) Quantifying errors associated with using prey skeletal structures from fecal samples to determine the diet of Steller's sea lion (Eumetopias jubatus). Mar Mamm Sci 19:724-744 
Tollit DJ, Heaslip S, Zepplelin T, Joy R, Call K, Trites AW (2004) A method to improve size estimates of walleye pollock (Theragra chalcogramma) and Atka mackerel (Pleurogrammus monopterygius) consumed by pinnipeds: digestion correction factors applied to bones and otoliths recovered in scats. Fish Bull 102:498-508

Tollit DJ, Schulze AD, Trites AW, Olesiuk PF and others (2009) Development and application of DNA techniques for validating and improving pinniped diet estimates. Ecol Appl 19:889-905

Tollit D, Pierce GJ, Hobson KA, Bowen WD, Iverson SJ (2010) Diet. In: Boyd IL, Bowen WD, Iverson SJ (eds) Marine mammal ecology and conservation: a handbook of techniques. Oxford University Press, Oxford, p 191-221

Towell RG, Ream RR, York AE (2006) Decline in northern fur seal (Callorhinus ursinus) pup production on the Pribilof Islands. Mar Mamm Sci 22:486-491

Tremblay Y, Cherel Y (2000) Benthic and pelagic dives: a new foraging behaviour in rockhopper penguins. Mar Ecol Prog Ser 204:257-267

Tremblay Y, Cherel Y (2003) Geographic variation in the foraging behaviour, diet and chick growth of rockhopper penguins. Mar Ecol Prog Ser 251:279-297

Tremblay Y, Shaffer SA, Fowler SL, Kuhn CE and others

Editorial responsibility: Per Palsbøll, Groningen, The Netherlands
(2006) Interpolation of animal tracking data in a fluid environment. J Exp Biol 209:128-140

* Trites AW, Calkins DG (2008) Diets of mature male and female Steller sea lions (Eumetopias jubatus) differ and cannot be used as proxies for each other. Aquat Mamm $34: 25-34$

*Vollenweider JJ, Heintz RA, Schaufler L, Bradshaw R (2011) Seasonal cycles in whole-body proximate composition and energy content of forage fish vary with water depth. Mar Biol 158:413-427

Wada E, Mizutani H, Minagawa M (1991) The use of stable isotopes for food web analysis. Crit Rev Food Sci Nutr 30: 361-371

*Waite JN, Trumble SJ, Burkanov VN, Andrews RD (2012) Resource partitioning by sympatric Steller sea lions and northern fur seals as revealed by biochemical dietary analyses and satellite telemetry. J Exp Mar Biol Ecol 416-417:41-54

*Ward TJ (2016) Fur seal Investigations 2013-2014, NOAA technical memorandum NMFS-AFSC-316. US Department of Commerce. doi:10.7289/V5/TM-AFSC-316

Keppelin TK, Orr AJ (2010) Stable isotope and scat analyses indicate diet and habitat partitioning in northern fur seals Callorhinus ursinus across the eastern Pacific. Mar Ecol Prog Ser 409:241-253

Submitted: May 22, 2017; Accepted: October 21, 2017 Proofs received from author(s): November 28, 2017 